\title{
In-use testing of disinfectants in hospitals
}

\author{
JEAN PRINCE AND G. A. J. AYLIFFE \\ Hospital Infection Research Laboratory, Summerfield Hospital, Birmingham 18
}

SYNOPSIS One hundred and five samples of clear, soluble phenolic disinfectants were obtained from varying sites in the wards of six hospitals. The concentration of disinfectant in each sample was measured by a colorimetric method and bacterial contamination was measured by an 'in-use' test and a membrane filter technique. The concentrations of disinfectant in $24 / 105(23 \%)$ samples were ?ㅇ? at the recommended level and $53(50.5 \%)$ were below. Bacterial contamination with Gram-negative $\mathcal{N}^{\circ}$ bacilli was found in 26/49 (53\%) samples containing less than $0.8 \%$ of disinfectant and $5 / 86(8.9 \%)$. samples containing more than $0.8 \%$. The concentrations in two of the heavily contaminated samples were $1.5 \%$ and $1.6 \%$ respectively.

The wide variety of disinfectants used in hospitals has been described in several surveys (eg, Public Health Laboratory Service Report, 1965; Ayliffe, Brightwell, Collins, and Lowbury, 1969). Since these reports were published, disinfectant policies have been introduced in many hospitals, but others either have no policy or still use expensive and often inappropriate disinfectants for treating the environment. The principles of formulating a policy were described by Kelsey (1970), and the 'in-use' dilutions are usually chosen from the manufacturers' recommendations or on the basis of the capacity test (Kelsey and Sykes, 1969). However, a laboratory test cannot reproduce the wide range of conditions which exist when the disinfectant is in use, and it is, therefore, advisable to carry out in-use tests for bacterial contamination (Kelsey and Maurer, 1966) when a new disinfectant is introduced into a hospital and at intervals afterwards. The in-use test will not determine whether contamination is due to an inadequate concentration of disinfectant or whether organisms are surviving or growing at or above the recommended concentration; inadequate concentrations of disinfectant in the absence of bacterial contamination will also not be detected.In thisstudy, concentrations of disinfectants were measured under in-use conditions by means of a colorimetric test and bacterial contamination was assessed by an in-use test (Kelsey and Maurer, 1966) and by a technique using a membrane filter.

\section{Methods}

Samples were collected from six hospitals, all of Received for publication 30 March 1972. which have disinfectant policy and mainly use a clear, soluble phenolic disinfectant, Stericol, for environmental disinfection. One hundred and five samples ? of solutions of the phenolic disinfectant were collected from mop buckets, toilet-brush holders, thermometer holders, containers for contaminated instruments, and other in-use situations. Some samples of chlorhexidine, Savlon, and other disinfectants were also collected.

COLORIMETRIC MEASUREMENT OF CONCENTRATION OF PHENOLIC DISINFECTANT Of $2 \%$ aminophenazone, $0.1 \mathrm{ml}$ and $9.8 \mathrm{ml}$ of $0.025 \%$ sodium carbonate were added to $0.1 \mathrm{ml}$ of the ? disinfectant. Then $0.1 \mathrm{ml}$ of $2 \%$ potassium ferricyanide was added, and after mixing readings were made in a spectrophotometer at $545 \mathrm{~nm}$. A standard curve was prepared from concentrations of the same disinfectant treated in the same way as the sample. The purple colour obtained is reasonably stable but should be read within one hour. If no spectrophotometer or colorimeter is available, an $N$ approximate assessment of the concentration can be obtained by comparing the colour of the test and standard solutions with the naked eye.

\section{BACTERIOLOGICAL CONTAMINATION}

\section{Direct culture method}

Five drops (0.02 $\mathrm{ml}$ per drop) from a standard pipette of the sample were placed on a well dried

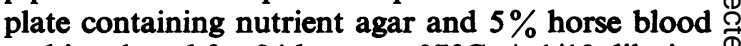
and incubated for 24 hours at $37^{\circ} \mathrm{C}$. A $1 / 10$ dilution $\stackrel{\complement}{\complement}$ of the disinfectant in lecithin-Tween 80 broth was made before the above procedure was carried out 
when chlorhexidine or quaternary ammonium compounds were examined. Counts were made of the number of colonies grown from the five drops. Further incubation of the plates or dilution of the disinfectant did not appear to influence the results with phenolic disinfectants in this study, but for routine testing, incubation for 72 hours at $37^{\circ} \mathrm{C}$ and at room temperature is advisable.

\section{Membrane filter method}

One $\mathrm{ml}$ of the disinfectant solution was filtered through an Oxoid membrane filter (pore size $0.45 \mu$ ) using a millipore sterifil filtration system. The filter was washed through with $20 \mathrm{ml}$ of broth, containing a neutralizer if necessary, and then transferred to a $5 \%$ blood agar plate. After incubation at $37^{\circ} \mathrm{C}$ for 24 hours, counts were made of the colonies growing on the membrane. Gram-negative bacilli were identified by the method of Cowan and Steel (1965).

\section{Results}

Table I shows that only $24 / 105$ of the samples were at the recommended concentration and many were much higher when measured by the colorimetric method. Some form of measurement was used in all

\begin{tabular}{lcccc}
\hline Hospital & $\begin{array}{l}\text { Total No. } \\
\text { of Samples }\end{array}$ & $\begin{array}{l}\text { No. Below } \\
\text { Recom- } \\
\text { mended } \\
\text { Concentra- } \\
\text { tion }\end{array}$ & $\begin{array}{l}\text { No. at } \\
\text { Recom- } \\
\text { mended } \\
\text { Concentra- } \\
\text { tion }\end{array}$ & $\begin{array}{l}\text { No. Above } \\
\text { Recom- } \\
\text { mended } \\
\text { Concentra- } \\
\text { tion }\end{array}$ \\
\hline 1 & & 8 & 3 & 4 \\
2 & 15 & 5 & 0 & 4 \\
3 & 9 & 17 & 7 & 8 \\
4 & 32 & 10 & 1 & 0 \\
5 & 11 & 5 & 10 & 2 \\
6 & 17 & 8 & 3 & 10 \\
Totals & 21 & 53 & 24 & 28 \\
\hline
\end{tabular}

Table I Variation in concentration of clear soluble phenolic disinfectant

${ }^{1}$ Hospitals $1-4,6$, recommended concentration $1 \%$, range $0 \cdot 8-1 \cdot 2 \%$ Hospital 5, recommended concentration $2 \%$, range $1 \cdot 8-2 \cdot 2 \%$ hospitals except hospital 6. The concentrations found in hospital 5 were more accurately measured than the others, since disinfectant was issued to the ward diluted ready for use.

\section{BACTERIAL CONTAMINATION OF SAMPLES}

A sample was considered to be contaminated if more than 50 organisms $/ \mathrm{ml}$ were grown, either on the membrane filter or in the in-use test, and using this criterion the results from both methods were similar; most contaminated samples contained more than 1000 organisms $/ \mathrm{ml}$. Table II shows that most samples containing less than $0.1 \%$ of disinfectant were contaminated $(11 / 13,84.6 \%)$; in samples containing between 0.1 and $0.8 \%$ of disinfectant, $15 / 36(41.6 \%)$ were contaminated, and when the concentration was between 0.8 and $2.0 \%, 5 / 34$ $(14.7 \%)$ were contaminated. None of the samples containing over $2.0 \%$ disinfectant was contaminated. The contaminating organisms were mainly $P$ s. aeruginosa or non-fermenting Gram-negative bacilli. At very low concentrations of disinfectant, Klebsiella sp. and Escherichia coli were commonly found, especially in mop buckets; spore-bearing bacilli were not included in the results. Table III shows the site of contamination and concentration of disinfectant of the five samples with a concentration at or above that recommended. All were contaminated with non-fermenting, non-pigmented, oxidase-positive, Gram-negative bacilli. On sub-

\begin{tabular}{lll}
\hline $\begin{array}{l}\text { Equipment in } \\
\text { Disinfectant } \\
\text { Solution }\end{array}$ & $\begin{array}{l}\text { Percentage } \\
\text { Concentration } \\
\text { of Disinfectant }\end{array}$ & $\begin{array}{l}\text { No. of } \\
\text { Organisms/ml in } \\
\text { Disinfectant Solution }\end{array}$ \\
\hline Sink mop & 0.95 & Uncountable \\
Floor mop & 0.9 & 50 \\
Floor mop & 1.5 & Uncountable \\
Floor mop & 0.9 & Uncountable \\
Cloth for surface & 1.6 & Uncountable \\
cleaning & 1.6 & \\
\hline
\end{tabular}

Table III Contamination of phenolic disinfectant solutions at concentrations above $0.8 \%$

Number of Contaminated Samples

\begin{tabular}{|c|c|c|c|c|c|c|c|}
\hline \multirow[t]{2}{*}{ Hospital } & \multicolumn{7}{|c|}{ Concentration of Disinfectant $(\%)$} \\
\hline & $0 \cdot 1$ & $0 \cdot 1-0.49$ & $0.5-0.79$ & $0 \cdot 8-1 \cdot 29$ & $1 \cdot 3-2$ & $>2 \cdot 0$ & Total \\
\hline $\begin{array}{l}1 \\
2 \\
3 \\
4 \\
5 \\
6\end{array}$ & $\begin{array}{r}1 / 1 \\
2 / 2 \\
3 / 3 \\
3 / 4 \\
0 \\
2 / 3\end{array}$ & $\begin{array}{l}1 / 1 \\
2 / 2 \\
2 / 7 \\
2 / 3 \\
0 / 1 \\
0 / 3\end{array}$ & $\begin{array}{r}5 / 6 \\
1 / 1 \\
0 / 7 \\
1 / 3 \\
0 \\
1 / 2\end{array}$ & $\begin{array}{r}1 / 3 \\
0 \\
1 / 7 \\
0 / 1 \\
0 / 1 \\
1 / 3\end{array}$ & $\begin{array}{c}0 / 2 \\
1 / 2 \\
0 / 2 \\
0 \\
0 / 12 \\
1 / 1\end{array}$ & $\begin{array}{r}0 / 2 \\
0 / 2 \\
0 / 6 \\
0 \\
0 / 3 \\
0 / 9\end{array}$ & $\begin{array}{l}8 / 15 \\
6 / 9 \\
6 / 32 \\
6 / 11 \\
0 / 17 \\
5 / 21\end{array}$ \\
\hline Total & $11 / 13(84 \%)$ & $7 / 17(41 \%)$ & $8 / 19(42 \%)$ & $3 / 15(20 \%)$ & $2 / 19(11 \%)$ & $0 / 22(0 \%)$ & $31 / 105(29 \%)$ \\
\hline
\end{tabular}

Table II Contamination and concentration of clear soluble phenolic disinfectant 
culture in nutrient broth these strains were inhibited by a concentration of $0.5 \%$ of disinfectant.

\section{Discussion}

Contamination of disinfectants was satisfactorily assessed by a simple in-use test (eg, Kelsey and Maurer, 1966); the membrane filter technique, although more accurately detecting small numbers of organisms, showed little advantage in testing phenolic disinfectants in the present study. It is probable that the membrane filter technique would be more useful for sampling solutions of chlorhexidine or quaternary ammonium compounds, but contamination of these compounds was too low in this study for assessment.

A simple colorimetric test for measuring the concentration of a phenolic disinfectant is a useful addition to the existing bacteriological tests. However, it should be emphasized that the chemical estimation described cannot replace the bacteriological in-use test for control purposes, since the activity of a disinfectant depends on formulation as well as phenol content. The study showed that measurement of disinfectants was inaccurate and that contamination was usually due to an inadequate concentration, ie, of 105 samples examined $26 / 49(53 \%)$ were contaminated when the concentration was less than $0.8 \%$ and only $5 / 56(8.9 \%)$ when the concentration was at or above this concentration. The isolation of organisms in large numbers in two of these samples containing $1.5 \%$ and $1.6 \%$ disinfectant respectively was clearly not due to inactivation of disinfectant, or to a recent addition of organisms since samples were not usually cultured until one to two hours after collection. The organisms were able to survive at a concentration which was usually rapidly bactericidal, but the property was rapidly lost, since on subculture the organisms were killed by 0.4 to $0.5 \%$ of disinfectant and resembled normally sensitive organisms. These strains may have become adapted to the higher phenolic concentrations or were possibly protected by a layer of protein which was lost on subculture. Adaptation of Pseudomonas cepacia to a 1 in 30 dilution of Savlon has been described (Bassett, 1971) and tolerance of the two organisms described here was increased again in laboratory experiments by habituation in increasing concentrations of the phenolic disinfectant to $1.0 \%$, but not as yet to $1.5 \%$. Contamination of diluted disinfectant in stock bottles was not found in the small number of samples examined in this survey, but there is always a risk of organisms surviving and possibly growing if containers are not washed and preferably disinfected before refilling.
The concentration of the disinfectant $(1 \%)$ recome mended for treatment of light contamination on the basis of the Kelsey-Sykes test is obviously adequate for most purposes, including floor mops, whict might be considered heavily contaminated. Most of the hospitals visited found it easier to use on concentration $(1 \%)$ although as indicated the con $\$$ centration found in practice was very variablew The use of $2 \%$, the concentration recommended for heavy contamination, might prevent all contam? ination, but would double the expense, increase the्E possibility of skin reactions, and it is still possible that organisms would become tolerant to the highes concentration. The use of a $1 \%$ solution and regulaiv in-use testing (eg, two to four times a year) should detect the appearance of resistant organisms and perhaps a policy involving rotation of types oक disinfectant should be considered; the possibility of cross-resistance between disinfectants requires furtherinvestigation. A more satisfactory answer would bE to reduce the use of disinfectant solutions in hospitak. Although equipment immersed in disinfectan $\vec{b}$ solution was found less often in hospital wards during this survey than in earlier surveys, inappro priate uses of disinfectants were still commonlo found. Many of the samples with inadequate con centrations were obtained from floor mop wated or water for washing surfaces, where the use of $\frac{0}{\phi}$ disinfectant was usually unnecessary. However mops do require disinfection after use and hea⿳亠丷厂巾 treatment is preferable to chemical disinfection (Colquitt and Maurer, 1969).

If a disinfectant is used at all the concentratio should be adequate, and a reliable method of measurement of disinfectant and diluent should be available. In hospital 5, disinfectant was issued to. the wards at the correct use-dilution. AlthougB clearly marked 'use undiluted', ward staff frequentl产 added a 'cupful' to a bucket; five samples showing inadequate concentrations were found in this hos pital. A further disadvantage of this method is that a considerable volume of water is unnecessaril $\overline{\bar{\alpha}}$ transported from the pharmacy to the wards. IR hospital 4 , bottles containing a measured amourf of undiluted disinfectant were issued to the ward Although this method should have been satisg factory 10/11 samples examined showed concentrab tions below that recommended. Domestic staf often used half a bottle or less, rather than the whole bottle for reasons of economy. The amount of water in the bucket was rarely measured althoug $\overline{\mathbf{Q}}$ the required level of water should have been marke $\$$ on the interior of the bucket. Hospitals 1, 2, and $\bar{T}$ used a dispensing pump attached to a container of undiluted disinfectant. Concentrations were very variable and obviously this technique was not af 
satisfactory as might be expected. Whichever technique of measurement is used, education of the domestic staff is obviously of major importance. A disinfectant policy will only work if it is understood and adhered to by all grades of staff. It would also be of value if policies involving other disinfectants were similarly assessed by chemical and bacteriological in-use tests.

We wish to thank the staff of the six hospitals for their cooperation.

References

Ayliffe, G. A. J., Brightwell, K. M., Collins, B. J., and Lowbury,
E. J. L. (1969). Varieties of aseptic practice in hospital wards. Lancet, 2, 1117-1120.

Bassett, D. C. J. (1971). The effect of $\mathrm{pH}$ on the multiplication of a pseudomonad in chlorhexidine and cetrimide. J. clin. Path., 24, 708-711.

Colquitt, H. R., and Maurer, I. M. (1969). Hygienic mop maintenance in hospitals. Brit. Hosp. J. Soc. Serv. Rev., 79, 2177-2179.

Cowan, S. T., and Steel, K. J. (1965). Manual for the Identification of Medical Bacteria. Cambridge University Press, London.

Kelsey, J. C. (1970). Disinfectants for hospital use: an interim statement. Brit. Hosp. J. Soc. Serv. Rev., 80, 521-522.

Kelsey, J. C., and Maurer, I. M. (1966). An in-use test for hospital disinfectants. Mon. Bull. Minist. Hlth. Lab. Serv., 25, $180-184$.

Kelsey, J. C., and Sykes, G. (1969). A new test for the assessment of disinfectants with particular reference to their use in hospitals Pharm. J., 202, 607-609.

Public Health Laboratory Service Committee on the Testing and Evaluation of Disinfectants (1965). Use of disinfectants in hospitals. Brit. med. J., 1, 408-413.

\section{Reports and Bulletins prepared by the Association of Clinical Biochemists}

The following reports and bulletins are published by the Association of Clinical Biochemists. They may be obtained from The Administrative Office, Association of Clinical Biochemists, 7 Warwick Court, Holborn, London, WC1R 5DP. The prices include postage, but air mail will be charged extra. Overseas readers should remit by British Postal or Money Order. If this is not possible the equivalent of $50 \mathrm{p}$ is the minimum amount that can be accepted.

SCIENTIFIC REPORTS

3 Automatic Dispensing Pipettes. An assessment of 35 commercial instruments 1967 P. M. G. BROUGHTON, A. H. GOWENLOCK, G. M. WIDDOWSON, and K. A. AHLQUIST 85p (\$2)

4 An Evaluation of five Commercial Flame Photometers suitable for the Simultaneous Determination of Sodium and Potassium March 1970 P. M. G. BROUGHTON and J. B. DAWSON $85 p(\$ 2)$

\section{SCIENTIFIC REVIEWS}

1 The Assessment of Thyroid Function March 1971 F. V. FLYNN and J. R. HOBBS $62 \frac{1}{2} \mathrm{p}(\$ 1.50)$

2 Renal Function Tests Suitable for Clinical Practice January 1972 F. L. MITCHELL, N. VEALL, and R. W. E. WATTS $62 \frac{1}{2} \mathrm{p}(\$ 1.50)$

\section{TECHNICAL BULLETINS}

9 Determination of Urea by AutoAnalyzer November

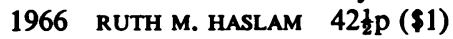

11 Determination of Serum Albumin by AutoAnalyzer using Bromocresol Green October 1967 B. E. NORTHAM

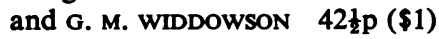

13 An Assessment of the Technicon Type II Sampler Unit March 1968 B. C. GRAY and G. K. MCGOWAN

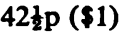

14 Atomic Absorption Spectroscopy. An outline of its principles and a guide to the selection of instruments May 1968 J. B. DAWSON and P. M. G. BROUGHTON $42 \mathrm{k}(\$ 1)$
15 A Guide to Automatic Pipettes (2nd edition) June 1968 P. M. G. BROUGHTON 42t $\frac{1}{2}$ (\$1)

16 A Guide to Automation in Clinical Chemistry May 1969 P. M. G. BROUGHTON 62⿺

17 Flame Photometers (2nd edition) 1969 P. WILDING $62 \frac{1}{\mathrm{z}} \mathrm{p}(\$ 1.50)$

18 Control Solutions for Clinical Biochemistry (4th edition) March 1970 P. M. G. BROUGHTON $62 \frac{1}{2} \mathrm{p}$ (\$1.50)

19 Spectrophotometers. A comparative list of low-priced instruments readily available in Britain May 1970

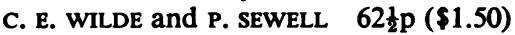

20 Quantities and Units in Clinical Biochemistry June 1970 P. M. G. BROUGHTON $62 \frac{1}{2} \mathrm{p}(\$ 1.50)$ More than 30 copies in units of 10 at $20 \mathrm{p}$

21 Filter Fluorimeters: A comparative list of 18 instruments September 1970 H. BRAUNSBERG and S. S. BROWN $62 \frac{1}{2} \mathrm{p}(\$ 1.50)$

22 Bilirubin standards and the Determination of Bilirubin by Manual and Technicon AutoAnalyzer Methods. January 1971 BARBARA BILLING, RUTH HASLAM, and N. WALD $62 \frac{1}{2} p(\$ 1.50)$

23 Interchangeable Cells for Spectrophotometers and Fluorimeters September 1971 E. S. BROWN and A. H. GOWENLOCK $62 \frac{1}{2} \mathrm{p}(\$ 1.50)$

24 Simple Tests to Detect Poisons March 1972 B. w. MEADE et al. $\quad 62 \frac{1}{2}(\$ 1.50)$ 